Article

\title{
Does Corporate Charitable Giving Help Sustain Corporate Performance in China?
}

\author{
Keling Wang ${ }^{1}$, Yaqiong Miao ${ }^{1}$, Ching-Hui (Joan) Su ${ }^{2, *}$, Ming-Hsiang Chen ${ }^{3,4,5}$, \\ Zhongjun $\mathrm{Wu}^{6, *}$ and Tie Wang ${ }^{7}$ \\ 1 School of Business and Tourism Management, Yunnan University, Kunming 650091, China; \\ kelingw@ynu.edu.cn (K.W.); sallymiao983@126.com (Y.M.) \\ 2 Department of Apparel, Events, and Hospitality Management, College of Human Sciences, \\ Iowa State University, Ames, IA 50011-1078, USA \\ 3 School of Hospitality Business Management, Carson College of Business, Washington State University, \\ Pullman, WA 99164-4742, USA; ming-hsiang.chen@wsu.edu \\ 4 Tourism and Social Administration College, Nanjing XiaoZhuang University, Nanjing 211171, China \\ 5 School of Business Administration, Anhui University of Finance and Economics, Bengbu 233030, China \\ 6 College of Tourism and Landscape Architecture, Guilin University of Technology, Guilin 541006, China \\ 7 Department of Tourism Management, School of Geography and Tourism, Research Center of Tourism \\ Development and Planning, Qufu Normal University, Rizhao 276826, China; tie.wang@qfnu.edu.cn \\ * Correspondence: joansu@iastate.edu (C.-H.S.); 2002013@glut.edu.cn (Z.W.); \\ Tel.: +1-515-294-5785 (C.-H.S.)
}

Received: 7 January 2019; Accepted: 6 March 2019; Published: 12 March 2019

\begin{abstract}
We examined whether corporate charitable giving (CCG) in China benefits corporate performance $(\mathrm{CP})$ in terms of sales growth $(S G)$, return on asset $(R O A)$, return on equity $(R O E)$, and Tobin's $Q(T Q)$, and revealed several findings. First, testing shows variation in the impact of CCG on CP. Whereas the ratio of corporate charitable giving (RCCG) to total sales revenue does not significantly enhance $S G, R O A$, and $R O E$, it is positively related to $T Q$. Second, the positive relationship between $R C C G$ and $T Q$ originates from non-state-owned firms (NSOFs) rather than state-owned firms (SOFs). Third, Chinese firms may use CCG as traditional philanthropy to enhance long-term performance instead of strategically using it to generate short-term performance. Lastly, an inverted U-shaped relationship exists between RCCG and TQ, especially for NSOFs.
\end{abstract}

Keywords: Chinese listed firms; corporate charitable giving; corporate performance

\section{Introduction}

As corporate charitable giving (CCG) is considered an essential tactic in managing political and business relationships, some studies have examined whether CCG can help improve corporate performance (CP). Previous studies have been done on the relationship between CCG and CP, indicating that CCG may be positively related to $\mathrm{CP}[1-4]$, negatively connected to $\mathrm{CP}[2,4,5]$, or may have no influence on $\mathrm{CP}$ at all [6-8]. Gao et al. [9] and Lin et al. [10] used event studies to evaluate the relationship between CCG and abnormal corporate returns in China and concluded that CCG is positively related to abnormal corporate returns. Gao et al. [9] also found that, although CCG is positively related to abnormal return within four days of an event, it is negatively related to return on asset $(R O A)$ during the event window. Wang and Qian [11] studied the relationship between CCG and corporate performance in China from 2001 to 2006 and discovered a significantly positive relationship between CCG and ROA but no link between CCG and market-to-book ratio.

The concept of CCG has infiltrated the media, academia, and business alike in China [10,12]. China, today, is the world's largest transition economy [13] and corporate charitable giving achieved 
85.9 billion RMB (accounted for 70.7\% of Chinese charitable donations) in 2015 [14], demonstrating that corporate giving plays a crucial role in China's philanthropic culture. Since 2003, the Chinese government has required publicly listed companies to report on corporate social responsibility (CSR), facilitating the collection of data and prompting researchers to start studying CCG. Researchers have since suggested that Chinese firms that engage in CCG have different motivations for giving than those in western economies $[9,10]$. Previous studies have pointed out that Chinese firms use CCG to create or maintain political connections [11,15-18] and that managers may use this benefit $[18,19]$. Wang and Qian [11] stated that, in China, CCG might help firms obtain social legitimacy and gain political access; Gao et al. [20] reported firms in China experience notable uncertainty concerning government policies, and CCG tends to cultivate good relationships with the government.

The demand for charitable giving is burgeoning in this fast-developing, emerging market as consumers are becoming more conscious of their social commitments [21] and firms experience the benefits through CCG $[2,3,14]$. Some studies have focused on the impact of CCG on CP in China $[9,10,22]$, but comparatively, little research has focused on the different effects of CCG on $\mathrm{CP}$ between state-owned firms (SOFs) and non-state-owned firms (NSOFs). Considering SOFs are prevalent in China $[10,13]$ and, by nature, are connected to the government, the managers of those firms do not have to worry about political access and government protection compared to those of NSOFs $[4,10]$. NSOFs tend to engage in CCG to build and maintain political connections $[13,17,19,23]$. Ma and Parish [18] stated that owners of private firms (i.e., limited liability companies in which two or more natural persons invest or that are controlled by a single natural person) were not allowed to join the Communist Party before 2001, so they engaged in CCG in exchange for legal status and political access. Lin et al. [17] found NSOFs that build political connections through CCG more easily gain access to government subsidies, or that the government rewards those firms with future subsidies, allowing them to outperform firms that did not create a connection with the government. NSOFs donated more and earlier than SOFs $[10,15]$.

The present study could serve as a quantitative measurement to determine how CCG potentially influences the CP of SOFs and NSOFs in China. We looked at longitudinal data collected from Chinese publicly listed firms between 2003 and 2016 to provide a comprehensive understanding of the effect of CCG on long-term CP and its differentiation between SOFs and NSOFs in China. We found most studies are event studies investigating the short-term financial impact, whereas longitudinal studies are not limited in scope and were used to display results demonstrating the long-term effects of CCG on financial performance through examining sales growth $(S G), R O A$, return on equity $(R O E)$, and Tobin's $\mathrm{Q}(T Q)$. Empirical test results from this study should lead to a better understanding of the extent to which CCG impacts on CP are different in China's SOFs and NSOFs.

The purpose of this study was to explore CCG's impact on Chinese firm CP through an analysis of empirical data. Three major results were produced from the testing model. First, CCG can improve firms' long-term $C P$ measures of $T Q$, but not short-term $C P$ measures of $S G, R O A$, and ROE. Second, the empirical results reveal that NSOFs initiate the impacts of CCG on CP, which means CCG can significantly enhance the long-term $\mathrm{CP}$ of NSOFs, but it cannot enhance long-term $\mathrm{CP}$ of SOFs. Finally, the results demonstrate that the positive impacts of CCG on long-term CP will be negative once CCG reaches the optimal point. Third, we found that, compared to western countries, the average portion of CCG to sales (RCCG) is low in China, which may be a possible reason that CCG cannot increase short-term $\mathrm{CP}$. The findings from this study not only shed light on the relationship between CCG and long-term CP among the different ownership firms in China, outlining important managerial implications, but also contribute to the finance research literature by extending Griffin and Mahon's model to understanding the link between corporate social performance and corporate financial performance in China's state ownership and corporate governance firms.

The remainder of this paper is divided into five main sections. Section 2 discusses the development of hypotheses. Section 3 describes the data and defines the study variables. Section 4 presents a test 
model and reports empirical results. Section 5 discusses and provides implications from the results of this study. Finally, Section 6 outlines some plans for future development.

\section{Literature Review}

Corporate charitable giving is a component of CSR defined as the donation of a portion of a firm's profits and/or resources to non-profit organizations in support of education, culture, healthcare, or natural disaster relief $[1,11,24]$. Yu and Choi [25] pointed out that previous studies [26-29] on the relationship between CSR and CP are inconclusive. Agle et al. [26] and Heinze et al. [27] both determined the relationship between CSR and CP to be positive, whereas Margolis and Walsh [29] noted a negative relationship, and Jin and Drozdenko [28] found no significant relationship between CSR and CP at all.

Since CCG is considered a discretionary dimension of CSR [30], making sense of the relationship between CCG and CP is challenging. Adopted by corporations as an aspect of CSR fulfillment, CCG is a public, academic, and government consideration [1,3,22,31,32]. Friedman's announcement that "the social responsibility of business is to increase its profit" [31] (p. 122) prompted a fierce debate about whether corporations should engage in philanthropic activity.

According to agency cost theory, CCG may distract managers' attention from profit maximization and exhaust corporate resources that should be dedicated to shareholders or other lucrative investments, hence damaging a firm's interests and shareholder value $[2,3,24]$. In other words, CCG is an additional agency cost that managers use to achieve status, power, security, and prestige $[2,33,34]$. Conversely, Navarro [3] claimed that CCG should be treated as an ordinary business expense based on profit maximization, and that firms can do well by doing good [35,36]. Based on value enhancement theory, however, CCG can potentially enhance branding and public recognition, attract employees, and grow consumer preference $[1,3,4]$, and researchers argue that CCG may maximize the value of a corporation.

Strategic philanthropy offers a compromise [37]. From the perspective of strategic management, a company's philanthropic strategy combines competitive maneuvering and business approaches that please customers to compete, as well as to achieve organizational objectives [38]. Strategic philanthropy is defined as corporate giving that benefits the community as well as the firm $[32,39,40]$ by realizing two goals-charity and profitability [8,32]. Sponsorship and cause-related promotion are naturally connected to marketing [39], so they are perceived as strategic philanthropy. Since the returns of CCG are difficult to measure [41,42], CCG may be a viable strategy for improving CP [1,32], or it may have no impact.

Porter and Kramer [32] noted that since corporations are part of society, CCG may enhance the corporate competitive context. CCG can integrate a corporation's social financial goals as a means to enhance long-term performance. Godfrey [1] assumed that CCG should be a rational decision in which managers should engage, stating that CCG potentially enhances $C P$ in two ways-by generating moral reputation capital that improves stakeholder and community perception of the corporation, thus adding strategic value to firm, and by furnishing insurance protection for firms in bad condition.

If CCG is used to acquire legitimacy or gain support from the government, it may not influence sales, so it is difficult to determine whether CCG directly benefits a firm's performance. Although Seifert et al. [8] (Figure 1) noted that strategic philanthropy addresses both charity and profitability, it is not definite whether CCG has true strategic value if it does not contribute to CP. They claimed that using traditional philanthropy to donate to causes will affect a corporation's long-term $\mathrm{CP}$ rather than short-term $\mathrm{CP}$, which is influenced by strategic philanthropy. 


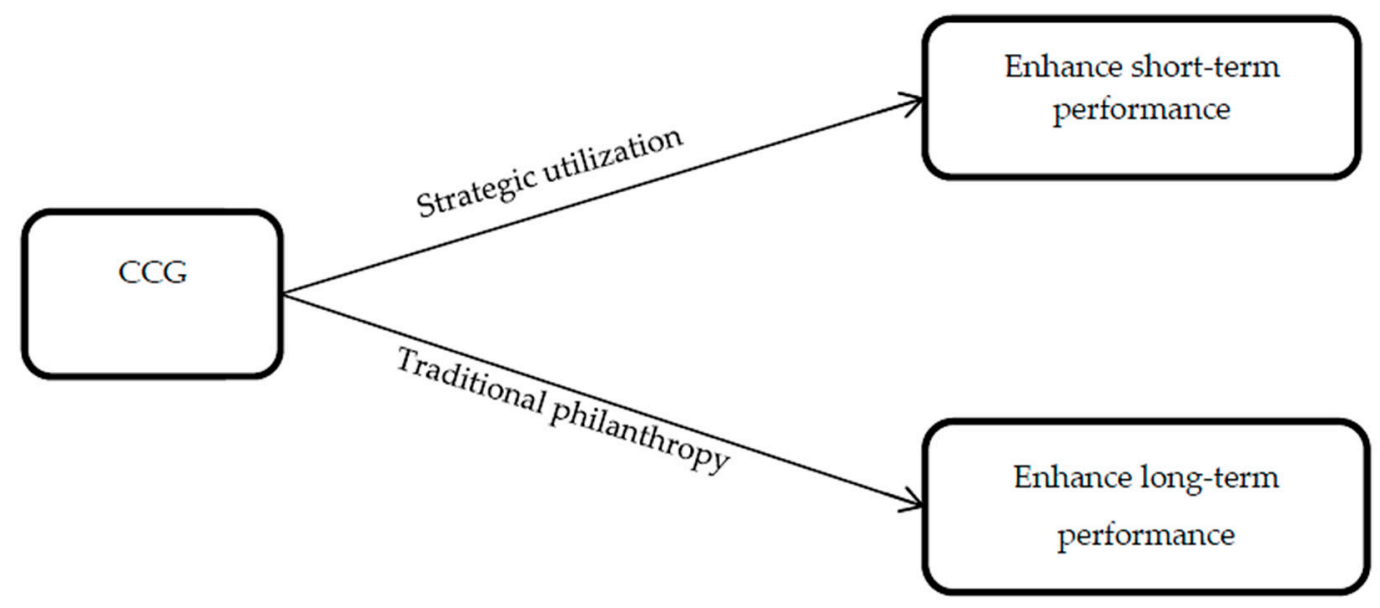

Figure 1. The relationship between corporate charitable giving (CCG) and corporate performance (CP) [8].

Previous empirical studies offer mixed findings $[3,4,6-8,24,36,43,44]$ about the relationship between CCG and $C P$, especially when using $R O A, R O E$, and return on sales (ROS) as the means of measurement. For example, Griffin and Mahon [7] found that CCG is not correlated with CP when measured by ROE, ROS, or ROA. Consistent with this study, Berman et al. [6] determined there is no significant relationship between CCG and CP when measured by $R O A$, and Seifert et al. [8] revealed a negligible impact of CCG on corporate stock performance. These studies indicated that CCG does not influence short-term CP. Lev et al. [36] argued that CCG from American companies enhances consumers' satisfaction and is positively related to sale growth, suggesting that CCG may increase future revenue growth. Hategan and Curea-Pitorac [44] provided evidence that CCG positively relates to $R O E$ and $T Q$ in Romania, and Liang and Renneboog [33] suggested that CCG positively influences financial performance and corporate value with its global sampling of firms.

Different from the studies mentioned above, Wang et al. [4] found links between CCG and CP measures of $R O A$ and $T Q$ are an inverse $U$-shape, indicating $R O A$ and $T Q$ improve as CCG increases and then deteriorate after CCG exceeds its optimal level. Chen and Lin [24] evaluated the hospitality industry in Taiwan and also found an inverted $\mathrm{U}$ relationship between CCG and CP measures of ROA, $R O E$, and TQ. Considering ROA and ROE are indicators of a corporation's current profitability, and TQ predicts a corporation's future growth, CCG may actually influence both short- and long-term CP.

\section{Development of Hypotheses}

Given that the impact that CCG has on CP is different according to geographic location [1,37], Wang et al. [43] studied the link between CCG and CP in the Chinese hospitality industry and found, for hotel firms, the relationship between CCG and $S G, R O A$, and ROE is an inverted U-shape. Both Chen and Lin [24] and Wang et al. [43] studied the impact of CCG on the CP of the hospitality industry, but the empirical results were inconsistent. With the majority of previous studies on CCG being conducted by researchers from the United States (U.S.) (74\%) and the United Kingdom (U.K.) $(13 \%)$ [45], Wang et al. [43] noted that there is limited research available to address the relationship between CCG and CP in China.

Lin et al. [10] studied how the market reacted to 136 firms' donation announcements after the Wenchuan earthquake and found a significantly positive relationship between CCG and corporate abnormal return that occurred for seven days. Gao et al. [9] did the same with an applied sample of 221 firms and found that the positive relationship between CCG and abnormal return continued for four days. Wang and Qian [11] further tested the relationship between CCG and CP measured by $R O A$ and market-to-book ratio and concluded CCG is positively related to $R O A$ but showed no significant connection between CCG and market-to-book ratio. Based on the premise that corporations 
may contribute CCG in an effort to intensify their firms' brand and consumer recognition, and that this will increase $\mathrm{CP}$ via sales growth $[1,3,36,37,46]$, we propose the following hypotheses:

Hypothesis Ia: CCG is positively related to short-term CP in China.

Hypothesis Ib: CCG is positively related to long-term CP in China.

Studies have pointed out that, in China, the government plays a crucial role in regulating and sometimes micromanaging the economy $[10,18-20,47]$. Firms in China may build or maintain a connection to the government through CCG, which results in the provision of more assistance from the government than firms who do not engage in CCG $[19,23]$. Accordingly, previous studies have shown that Chinese firms engage in charitable donations to build or maintain links with the government in order to establish legitimacy or obtain government subsidiaries [15-17].

The risks and purpose of SOFs and NSOFs for engaging in CCG are different [48]. SOFs are naturally connected to the government and have easier access to political and financial support including business licenses, subsidiaries, loans from state-owned banks, and sales channels $[49,50]$. So, the managers of those firms do not worry as much about political access and government protection $[4,11]$. Compared to SOFs, NSOFs are more willing to donate and to donate more $[10,13,17,19,51]$. Ma and Parish [18] claimed that, in the 1990s, NSOFs donated to government welfare programs in exchange for political access and legitimacy. NSOFs in China are more likely to donate in order to build or maintain political connections [17], making it easier for NSOFs to obtain legitimacy and critical resources from the government [23,51] and loans from stated-owned banks [19]. Based on these findings, we propose the following hypothesis:

Hypothesis II: The positive impact of CCG on CP is more significant for NSOFs than for SOFs.

Godfrey [1] pointed out there is an optimal point at which CCG increases CP, and Wang et al. [4] found a curvilinear relationship between CCG and CP. Specifically, both researchers noted that the relationship between CCG and ROA, as well as between CCG and TQ, is an inverted U-shape, which indicates an optimal level that, once surpassed, produces a decrease in $R O A$ and TQ. Chen and Lin [24] studied CCG's effect on hospitality firm performance in Taiwan and found that CCG influences ROA, $R O E$, and TQ in an inverted U-shape, suggesting that higher CCG leads to higher ROA, ROE, and $T Q$. However, once CCG surpasses the optimal point, the effects of CCG on ROA, ROE, and TQ become negative.

Wang et al. [43] tested the link between CCG and CP (measured by sale growth, ROA, ROE, and $T Q$ ) in the Chinese hospitality industry; however, they did not find the same conclusion. The Chinese study pointed to an inverted U-shape relationship between CCG and SG, ROA, and ROE in the hotel industry, which suggests CCG can enhance $R O A$ and $R O E$ by increasing $S G$ before CCG reaches the optimal level. Once it surpasses the optimal level, $S G, R O A$, and $R O E$ will decrease. This study also revealed that CCG does not significantly affect hotel firms' future growth as measured by $T Q$.

Since CCG transfers wealth from firms to society [1] and is a kind of cost for firms [3], it is valuable to investigate if an optimal point of the impact of CCG exists on short- and long-term CP in China. Thus, based on Hypothesis I, we propose the following hypothesis:

Hypothesis III: There is an optimal point of the positive relationship between CCG and CP, and once CCG exceeds the optimal point, the relationship reverses to produce a negative impact.

Given that Wang and Qian [11] tested the relation between CCG and CP in Chinese firms, it is necessary to distinguish our study from theirs. First, they adopted $R O A$ and market-to-book ratio as $C P$ measures, whereas this study applies $S G, R O A$, and $R O E$ as measures of short-term $C P$, and 
$T Q$ as a measure of long-term CP, in order to identify how CCG specifically influences CP. Second, this study relies on longitudinal data from 2835 firms between 2003 and 2016 to test the effect CCG on CP, whereas Wang and Qian [11] used a sample of 1453 firms from 2001 to 2006. During this period, the sample of publicly listed firms nearly doubled, so the longitudinal data provide a more comprehensive understanding of the effect of CCG on CP. Third, we tested the optimal level of CCG. Whereas Wang and Qian's [11] test showed a significant positive link between CCG and ROA, they did not consider the optimal level of CCG. Considering that CCG is a rational arrangement of corporate resources, it is necessary to determine the optimal point of CCG.

\section{Data and Variables}

The total value of CCG in China in 2003 was 3.33 billion RMB (Figure 2), and it reached 13.37 billion RMB in 2016, which is an increase of almost $302 \%$. Considering the ratio of CCG to sales (RCCG), RCCG increased from $0.029 \%$ to $0.039 \%$ from 2004 to 2011 , respectively, except in $2008(0.09 \%)$ when the Wenchuan, Sichuan earthquake struck, and in 2010 (0.054\%) when the Yushu, Qinghai earthquake hit. Since 2011, RCCG decreased each year, even when a 7.0 earthquake struck Yaan, Sichuan in 2013. In 2016, RCCG was $0.029 \%$, which is the same as in 2003. While the number of donations increased, $R C C G$ declined. This data prompted us to question why the proportion of CCG to sales is decreasing, and how CCG influences firm performance in China. In order to answer these questions, it is necessary to understand the relationship between CCG and CP.

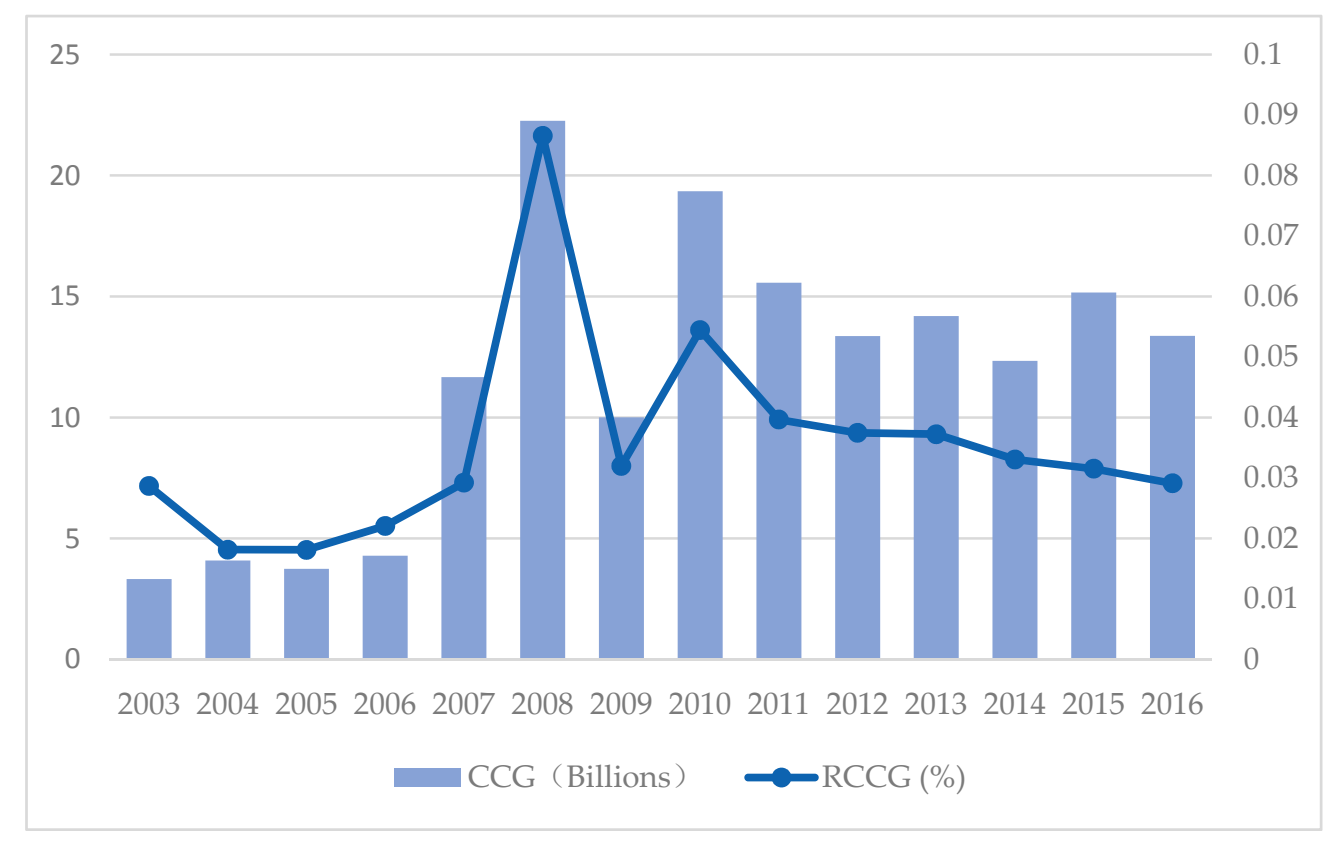

Figure 2. The total value of CCG and RCCG in China 2003-2016.

\subsection{Data Collection}

The sample for this study was composed of all listed firms on the Shenzhen and Shanghai Stock Exchange between 2003 and 2016. The sample consisted of an unbalanced panel with 2835 firms, excluding the finance industry as their accounting standards are different from other industries. After removing abnormal data and unavailable data years, there were approximately 25,487 firm-year observations that contained the independent variable CP measures of $S G, R O A, R O E$, and $T Q$, and dependent variable CCG measures of corporate giving in cash/sale growth (RCCG).

The corporate performance data of each year and the measurement of firm ownership were collected from the China Stock Market and Accounting Research (CSMAR) database [52]. We collected CCG in cash information from corporate annual reports through the China Information [53] - the 
official information-disclosure website for publicly listed firms appointed by the China Securities Regulatory Commission.

\subsection{Variables}

Consistent with Brammer and Millington [54], Chen and Lin [24], and Lev et al. [36], we adopted the ratio of corporate charitable giving (CCG) to sales revenue (SR) as the independent variable $(R C C G)$ :

$$
R C C G_{\mathrm{t}}=C C G_{\mathrm{t}} / S R_{t} \times 100 \% .
$$

We use sales growth rate (SG), ROA, ROE, and Tobin's Q (TQ) to measure firm performance (please note that we have examined the impact of RCCG on stock return, and test results showed that RCCG has no significant effect on stock returns for SOFs and NSOFs). SG represents consumer preference. $R O A$ is a signal of asset use, and $R O E$ is commonly used to measure profitability. $T Q$ is a measure of future growth opportunity.

SG is calculated as:

$$
S G_{\mathrm{t}}=\left(S R_{t}-S R_{t-1}\right) /\left(S R_{t-1}\right) \times 100 \% .
$$

Two common profitability measures, $\mathrm{ROA}$ and $\mathrm{ROE}$, are defined as:

$$
\begin{aligned}
& R O A_{t}=N I_{t} / T A_{t} \\
& R O E_{t}=N I_{t} / T E_{t}
\end{aligned}
$$

where NI denotes net income, TA represents total assets, and TE is total equity. We follow Chen and Lin [24] in using $T Q$ to measure future growth opportunity:

$$
T Q_{t}=M V_{t} / R V_{t}
$$

where MV is a firm's market value, computed as the sum of the market value of common stock plus the book value of preferred stock and debt, and RV is the replacement value of its assets, defined as the book value of total assets [55]. A firm with a larger, long-term growth opportunity is expected have a higher TQ. Note that only RCCG and SG are percentages; ROA, ROE, and TQ are not.

The first control variable is the company's debt ratio $(L E V)$ and is calculated as total debt divided by total assets. The total debt and total assets are the values at the end of each year. A high LEV implies the company has high principal and interest payments and lacks sufficient cash flow for meeting its debt obligations. Thus, $L E V$ is expected to be negatively related to a firm's performance.

The second control variable is firm size (SIZE) and is derived from the natural logarithm of the total assets. The variable SIZE is expected to have a positive effect on a firm's performance because larger firms would have greater market power and greater ability to adjust to economic and social changes in order to perform well [47].

The third control variable is a dummy variable of state-ownership (SOP). Li et al. [16] claimed that $60.43 \%$ of firms were controlled by the state in China, and that, compared to SOFs, NSOFs are more likely to build political connections through CCG in order to gain resources controlled by the government. For that reason, we used SOP as a dummy variable. The CSMAR database provides corporate governance structure and assigns a value of 1 to a state-owned company that is ultimately controlled by Chinese governments at all levels and a value of 0 to non-state-owned companies that are controlled by a private entity or a family $[10,16,22]$.

Table 1 summarizes the statistics of the study variables. The mean value of SOP was 0.4875 , meaning $48.75 \%$ of our sample firms were SOFs (1382 firms) compared to $60.43 \%$ in 2013 [16,22]. This shows that, following China's joint-stock reform, the number of stated-owned firms decreased. From 2003 to 2016 , RCCG ranged from $0.00 \%$ to $0.98 \%$ with a mean of $0.03 \%$ and a standard deviation of $0.08 \%$, suggesting that Chinese listed companies spent $0.03 \%$ of their sales revenue on CCG. NSOFs 
had a higher value of RCCG than SOFs. The mean of RCCG for NSOFs $(0.04 \%)$ was two times that of SOFs $(0.02 \%)$.

Table 1. Descriptive statistics of study variables.

\begin{tabular}{|c|c|c|c|c|c|c|c|c|}
\hline $\begin{array}{c}\text { All listed } \\
\text { SOFs and NSOFs } \\
N=22,652\end{array}$ & $R C C G$ & $R O A$ & $R O E$ & $T Q$ & $S G$ & SIZE & $L E V$ & $S O P$ \\
\hline Minimum & 0.00 & -48.32 & -167.11 & 0.01 & -1.05 & 16.52 & 0.01 & 0 \\
\hline Maximum & 0.98 & 4.84 & 37.14 & 91.58 & 461.03 & 28.51 & 96.96 & 1 \\
\hline Mean & 0.03 & 0.03 & 0.03 & 2.16 & 0.50 & 21.71 & 0.54 & 0.4875 \\
\hline Std. Dev. & 0.08 & 0.48 & 1.78 & 2.91 & 2.63 & 1.33 & 1.60 & 0.50 \\
\hline $\begin{array}{c}\text { SOFs } \\
N=11,043\end{array}$ & $R C C G$ & $R O A$ & $R O E$ & $T Q$ & $S G$ & SIZE & $L E V$ & \\
\hline Minimum & 0.00 & -6.78 & -72.15 & 0.01 & -1.05 & 16.76 & 0.01 & \\
\hline Maximum & 0.94 & 4.84 & 37.14 & 76.09 & 190.21 & 28.51 & 8.61 & \\
\hline Mean & 0.02 & 0.02 & 0.03 & 1.60 & 0.30 & 22.10 & 0.53 & \\
\hline Std. Dev. & 0.06 & 0.11 & 1.20 & 1.98 & 2.93 & 1.38 & 0.29 & \\
\hline $\begin{array}{c}\text { NSOFs } \\
N=11,609\end{array}$ & RCCG & $R O A$ & $R O E$ & $T Q$ & $S G$ & SIZE & $L E V$ & \\
\hline Minimum & 0.00 & -48.32 & -167.11 & 0.06 & -1.00 & 16.52 & 0.01 & \\
\hline Maximum & 0.98 & 2.64 & 26.06 & 91.58 & 461.03 & 27.45 & 96.96 & \\
\hline Mean & 0.04 & 0.02 & 0.02 & 2.74 & 0.63 & 21.46 & 0.48 & \\
\hline Std. Dev. & 0.10 & 0.52 & 2.26 & 3.46 & 10.55 & 1.10 & 1.35 & \\
\hline
\end{tabular}

Notes: $\mathrm{N}$ is the number of firm-year observations. Only RCCG and sales growth (SG) are percentages among all variables.

As exhibited in Table 1, SOFs have the same mean values of ROA as NSOFs, though SOFs have higher mean values of ROE, $L E V$, and firm size, and NSOFs have higher values of $T Q$ and $S G$. The statistics suggest, in general, that SOFs have a higher debt ratio and larger firm size, whereas NSOFs perform better in sales growth and future growth.

\section{Panel Regression Test and Empirical Results}

\subsection{RCCG Significantly Enhances Long-Term CP Rather than Short-Term CP}

To test the effect of RCCG on short- and long-term CP, we applied panel regression based on data from nearly 2835 Chinese companies that were publicly traded between 2003 to 2016. The panel regression specified the time-varying relationship between RCCG and CP variables, provided control for the heterogeneity of individual firms, and reduced the problems associated with multicollinearity and estimation bias [56,57].

In order to evaluate if RCCG can enhance $\mathrm{CP}$, we calculated the following panel regression tests, applying the short-term $\mathrm{CP}$ measures of $S G, R O A$, and $R O E$ to test Hypothesis Ia, and using the long-term $\mathrm{CP}$ measure of $T Q$ to test Hypothesis Ib:

$$
C P_{i, t}=\beta_{01}+\beta_{11} R C G G_{i, t}+\beta_{21} L E V_{i, t}+\beta_{31} S I Z E_{i, t}+\beta_{41} S O P_{i, t}+\varepsilon_{i, t}
$$

where $\mathrm{CP}_{i, t}$ denotes $i$ firm's short-term performance measures of $S G, R O A$, and $R O E$ in time $t$, and long-term performance measure of $T Q$ in time $t$. Note that when running all panel regression tests, in addition to controlling the year effect, we used the F-test and the Hausman tests [58] to determine whether pooled ordinary least square (OLS), fixed effects, or random effects would be the appropriate estimation method [59].

Based on the F-test, the fixed effects model outperforms the pooled OLS when the null hypothesis indicates that the pooled OLS model is more appropriate than the fixed effects model ( $F$-statistic is greater than F-test critical value). Accordingly, when the fixed effects method is more appropriate than the pooled OLS method, we performed the Hausman test [58] to see if the fixed or random effects 
method should be used when performing panel regression test. The fixed effects model was selected if the test statistic was significantly larger than the critical value, rejecting the null hypothesis that the random effects model is more appropriate than the fixed effects model.

As shown in Table 2, the coefficients of RCCG and SG (Panel A), ROA (Panel B), and ROE (Panel C) were not statistically significant at the $10 \%$ level, but the coefficient of RCCG on TQ (Panel D) was statistically significant at the $10 \%$ level, and the explanatory power of RCCG on TQ was $12 \%$ according to the adjusted $R^{2}$. Test results failed to support Hypothesis Ia-that CCG can improve short-term $\mathrm{CP}$-but they do support Hypothesis Ib-that CCG can benefit long-term CP. According to the panel regression results, our findings show partial differences from our expectation that $L E V$ should be negatively related to CP. The result shows $L E V$ positively influenced $S G$ at the $10 \%$ level, but was negatively related to $R O A$ and $R O E$ at the $1 \%$ level, and was negatively related to $T Q$ without significance. SIZE was positively related to $S G, R O A$, and $R O E$ at the $1 \%$ level but negatively related to $T Q$ at the $1 \%$ level, which differs partially from our assertion that firm size should be positively related to $C P$. The relationships between $S O P$ and $S G$, and $S O P$ and $T Q$, were both significantly negative at the $1 \%$ level, and the coefficient of $S O P$ and $R O A$ was negative but insignificant.

Table 2. Panel regression test results of RCCG on all listed state-owned firms' (SOFs) and non-state-owned firms' (NSOFs) performance.

\begin{tabular}{|c|c|c|c|c|c|c|c|c|c|}
\hline \multirow{2}{*}{$\begin{array}{c}\text { Panel A: SG } \\
\text { (Pooled OLS) }\end{array}$} & \multirow{2}{*}{ Coefficient } & \multirow{2}{*}{$t$-statistic } & \multirow{2}{*}{$p$-value } & \multirow{2}{*}{ Adjusted $R^{2}$} & Panel B: $R O A$ & \multirow{2}{*}{ Coefficient } & \multirow{2}{*}{$t$-statistic } & \multirow{2}{*}{$p$-value } & \multirow{2}{*}{ Adjusted $R^{2}$} \\
\hline & & & & & (Pooled OLS) & & & & \\
\hline Constant & -1.91 & -1.82 & $0.07^{* *}$ & 0.00 & Constant & -0.19 & -3.68 & $0.00^{* * *}$ & 0.16 \\
\hline RCCG & -0.86 & -1.14 & 0.26 & & RCCG & 0.02 & 0.61 & 0.55 & \\
\hline$L E V$ & 0.15 & 1.66 & $0.10^{*}$ & & $L E V$ & -0.19 & -67.66 & $0.00^{* * *}$ & \\
\hline SIZE & 0.12 & 2.56 & $0.01^{* * *}$ & & SIZE & 0.01 & 6.03 & $0.00^{* * *}$ & \\
\hline \multirow{2}{*}{$S O P$} & -0.55 & -4.29 & $0.00^{* * *}$ & & $S G$ & 0.00 & 1.42 & 0.15 & \\
\hline & & & & & $S O P$ & -0.01 & -0.87 & 0.38 & \\
\hline $\begin{array}{l}\text { Panel C: ROE } \\
\text { (Pooled OLS) }\end{array}$ & Coefficient & $t$-Statistic & Prob. & Adjusted $R^{2}$ & $\begin{array}{c}\text { Panel D: } T Q \\
\text { (Fixed effects) }\end{array}$ & Coefficient & $t$-Statistic & Prob. & Adjusted $R^{2}$ \\
\hline Constant & -0.56 & -2.75 & $0.01^{* * *}$ & 0.00 & Constant & 44.73 & 68.52 & $0.00^{* * *}$ & 0.12 \\
\hline RCCG & 0.16 & 1.09 & 0.28 & & RCCG & 0.57 & 2.54 & $0.01^{* * *}$ & \\
\hline LEV & -0.02 & -2.07 & $0.04^{* *}$ & & LEV & -0.02 & -0.65 & 0.52 & \\
\hline SIZE & 0.03 & 2.91 & $0.00^{* * *}$ & & SIZE & -1.94 & -64.89 & $0.00^{* * *}$ & \\
\hline$S G$ & 0.00 & 0.55 & 0.58 & & $S G$ & 0.00 & 2.25 & $0.02^{* *}$ & \\
\hline SOP & 0.00 & -0.15 & 0.88 & & $S O P$ & -0.44 & -5.24 & $0.00^{* * *}$ & \\
\hline
\end{tabular}

Notes: * Significant at the $10 \%$ level. ${ }^{* *}$ Significant at the $5 \%$ level. ${ }^{* *}$ Significant at the $1 \%$ level.

\subsection{Impact of CCG on Long-Term CP is Significant for NSOFs}

Table 3 presents the estimation of Equation (6) for SOFs with the panel regressions showing that the variable RCCG was not associated with short-term CP measures of $S G$ (Panel A), ROA (Panel B), or ROE (Panel C), and long-term CP measures the TQ (Panel D) for SOFs. Notably, we found that SIZE was negatively related to SOFs' $T Q$. Panel regression results show $L E V$ was negatively related to $R O A$ and TQ at the $1 \%(0.5 \%)$ level, whereas SIZE was positively related to ROA and ROE at the $1 \%(5 \%)$ level but negatively related to $T Q$ at the $1 \%$ level. $S G$ had no significant link with $R O A, R O E$, or $T Q$.

Table 4 presents the empirical results of NSOFs, and the panel regressions show that RCCG did not significantly influence $S G$ (Panel A) or short-term CP measures ROA (Panel B) and ROE (Panel C). However, Panel D shows the coefficient of RCCG and TQ was significantly positive at the $10 \%$ level, and the explanatory power of RCCG on TQ for NSOFs was 73\% according to the adjusted $R^{2}$. Empirical test results show $L E V$ was negatively related to $R O A$ at the $1 \%$ level and was positively related to $T Q$ at the $1 \%$ level. The positive relationships between SIZE and SG and ROE are significant at the 5\% (1\%) level, but SIZE was negatively related to TQ at the $1 \%$ level. SG had no significant influence on ROA, ROE, or TQ. The results in Tables 3 and 4 support Hypothesis II-that the impact of CCG on CP is different for SOFs and NSOFs. 
Table 3. Panel regression test results of RCCG on SOFs' performance.

\begin{tabular}{|c|c|c|c|c|c|c|c|c|c|}
\hline \multirow{2}{*}{$\begin{array}{c}\text { Panel A: SG } \\
\text { (Pooled OLS) }\end{array}$} & \multirow{2}{*}{ Coefficient } & \multirow{2}{*}{$t$-Statistic } & \multirow{2}{*}{ Prob. } & \multirow{2}{*}{ Adjusted $R^{2}$} & Panel B: $R O A$ & \multirow{2}{*}{ Coefficient } & \multirow{2}{*}{$t$-Statistic } & \multirow{2}{*}{ Prob. } & \multirow{2}{*}{ Adjusted $R^{2}$} \\
\hline & & & & & (Fixed Effects) & & & & \\
\hline Constant & -0.67 & -0.73 & 0.46 & 0.00 & Constant & -1.02 & -6.15 & $0.00^{* * *}$ & 0.40 \\
\hline RCCG & -0.32 & -0.35 & 0.72 & & RCCG & -0.08 & -1.21 & 0.23 & \\
\hline$L E V$ & 0.24 & 1.37 & 0.17 & & $L E V$ & -1.37 & -79.19 & $0.00^{* * *}$ & \\
\hline \multirow[t]{2}{*}{ SIZE } & 0.04 & 0.98 & 0.33 & & SIZE & 0.08 & 10.71 & $0.00^{* * *}$ & \\
\hline & & & & & $S G$ & 0.00 & -0.29 & 0.77 & \\
\hline Panel C: $R O E$ & \multirow{2}{*}{ Coefficient } & \multirow{2}{*}{$t$-Statistic } & \multirow{2}{*}{ Prob. } & \multirow{2}{*}{ Adjusted $R^{2}$} & Panel D: $T Q$ & \multirow{2}{*}{ Coefficient } & \multirow{2}{*}{$t$-Statistic } & \multirow{2}{*}{ Prob. } & \multirow{2}{*}{ Adjusted $R^{2}$} \\
\hline (Pooled OLS) & & & & & (Fixed Effects) & & & & \\
\hline Constant & -0.36 & -1.68 & $0.09^{*}$ & 0.00 & Constant & 30.10 & 48.22 & $0.00^{* * *}$ & 0.54 \\
\hline RCCG & 0.12 & 0.56 & 0.57 & & RCCG & 0.29 & 1.19 & 0.24 & \\
\hline$L E V$ & -0.05 & -1.21 & 0.23 & & $L E V$ & -0.17 & -2.17 & $0.03^{* *}$ & \\
\hline SIZE & 0.02 & 1.98 & $0.05^{* *}$ & & SIZE & -1.29 & -45.41 & $0.00^{* * *}$ & \\
\hline$S G$ & 0.00 & 0.18 & 0.86 & & $S G$ & 0.00 & 0.87 & 0.38 & \\
\hline
\end{tabular}

Notes: * Significant at the $10 \%$ level. ${ }^{* *}$ Significant at the $5 \%$ level. ${ }^{* * *}$ Significant at the $1 \%$ level.

Table 4. Panel regression test results of RCCG on NSOFs' performance.

\begin{tabular}{|c|c|c|c|c|c|c|c|c|c|}
\hline \multirow{2}{*}{$\begin{array}{c}\text { Panel A: SG } \\
\text { (Pooled OLS) }\end{array}$} & \multirow{2}{*}{ Coefficient } & \multirow{2}{*}{$t$-Statistic } & \multirow{2}{*}{ Prob. } & \multirow{2}{*}{ Adjusted $R^{2}$} & Panel B: $R O A$ & \multirow{2}{*}{ Coefficient } & \multirow{2}{*}{$t$-Statistic } & \multirow{2}{*}{ Prob. } & \multirow{2}{*}{ Adjusted $R^{2}$} \\
\hline & & & & & (Pooled OLS) & & & & \\
\hline Constant & -3.98 & -1.88 & $0.06^{* *}$ & 0.00 & Constant & 0.04 & 0.40 & 0.69 & 0.21 \\
\hline RCCG & -1.20 & -1.04 & 0.30 & & RCCG & 0.03 & 0.55 & 0.58 & \\
\hline$L E V$ & 0.00 & 0.21 & 0.83 & & $L E V$ & -0.17 & -55.98 & $0.00^{* * *}$ & \\
\hline \multirow[t]{2}{*}{ SIZE } & 0.22 & 2.28 & $0.02^{* *}$ & & SIZE & 0.00 & 0.84 & 0.40 & \\
\hline & & & & & $S G$ & 0.00 & 1.27 & 0.20 & \\
\hline Panel C: $R O E$ & \multirow{2}{*}{ Coefficient } & \multirow{2}{*}{$t$-Statistic } & \multirow{2}{*}{ Prob. } & \multirow{2}{*}{ Adjusted $R^{2}$} & Panel D: $T Q$ & \multirow{2}{*}{ Coefficient } & \multirow{2}{*}{$t$-Statistic } & \multirow{2}{*}{ Prob. } & \multirow{2}{*}{ Adjusted $R^{2}$} \\
\hline (Pooled OLS) & & & & & (Fixed Effects) & & & & \\
\hline Constant & -0.99 & -2.54 & $0.01^{* * *}$ & 0.00 & Constant & 77.48 & 34.09 & $0.00^{* * *}$ & 0.73 \\
\hline RCCG & 0.18 & 0.86 & 0.39 & & RCCG & 1.13 & 1.70 & $0.09^{*}$ & \\
\hline$L E V$ & 0.00 & 0.88 & 0.38 & & $L E V$ & 2.36 & 364.31 & $0.00^{* * *}$ & \\
\hline SIZE & 0.05 & 2.59 & $0.01^{* * *}$ & & SIZE & -3.53 & -33.35 & $0.00^{* * *}$ & \\
\hline$S G$ & 0.00 & 0.44 & 0.66 & & $S G$ & 0.00 & 0.81 & 0.42 & \\
\hline
\end{tabular}

Notes: * Significant at the $10 \%$ level. ${ }^{* *}$ Significant at the $5 \%$ level. ${ }^{* * *}$ Significant at the $1 \%$ level.

\subsection{Optimal Level of RCCG on CP}

To test the optimal level of RCCG on sales (i.e., consumer preference) and CP (measured by $S G$, $R O A, R O E$, and $T Q$ ), we included both the linear and quadratic terms for $R C C G$ in the regression equation and performed the following panel regression tests:

$$
C P_{i, t}=\lambda_{01}+\lambda_{11} R C C G_{i, t}+\lambda_{21} R C C G_{i, t}^{2}+\lambda_{31} L E V_{i, t}+\lambda_{41} S I Z E_{i, t}+\lambda_{51} S O P_{i, t}+\varepsilon_{i, t}
$$

where $\mathrm{CP}_{i, t}$ denotes $i$ firm's short-term performance in terms of $S G, R O A$, and $R O E$ at time $t$, and long-term performance in terms of $T Q$ at time $t$.

According to the framework given in Equation (7), the optimal level of RCCG on CP exists if $\gamma_{21}$ and $\lambda_{21}$ are significantly different from zero. There is a U-shaped or an inverted U-shaped effect of RCCG on firm performance if $\gamma_{11}, \lambda_{11}, \gamma_{21}$, and $\lambda_{21}$ are significantly different from zero. For example, if $\gamma_{11}=0, \lambda_{11}=0$ and $\gamma_{21}=0$ and $\gamma_{21}=0$ are rejected, and $\gamma_{11}<0\left(\gamma_{11}>0\right), \lambda_{11}<0\left(\lambda_{11}>0\right)$, and $\gamma_{21}>$ $0\left(\gamma_{21}<0\right)$ and $\lambda_{21}>0\left(\lambda_{21}<0\right)$, there is a (an inverted) U-shaped relationship between RCCG and firm performance. The relationship between RCCG and firm performance is linear instead of curvilinear if $\gamma_{11}=0$ and $\lambda_{11}=0$ are rejected and $\gamma_{21}=0$ and $\lambda_{21}=0$ are not rejected.

We also used the F-test and the Hausman tests [58] to determine whether OLS, fixed effects, or random effects would be appropriate estimation methods when performing panel regression tests [59]. Panel regression test results of RCCG and $R C C G^{2}$ on $S G$, short-term CP, and long-term CP are summarized in Table 5 for all listed firms, Table 6 for SOFs, and Table 7 for NSOFs. As shown in Tables 5-7, the effects of RCCG and $R C C G^{2}$ on $S G$ and short-term performance of ROA and ROE for all listed firms are not statistically significant at the $10 \%$ level with low explanatory power (adjusted $R^{2}$ 
value). After all listed firms were divided into SOFs (Table 6) and NSOFs (Table 7), the results were consistent with the results from all listed firms, indicating that RCCG and RCCG ${ }^{2}$ do not significantly affect $S G$ (Panel A) or short-term performance of ROA (Panel B) or ROE (Panel C).

Table 5. Panel regression test results of RCCG and $R C C G^{2}$ on all listed SOFs and NSOFs' performance.

\begin{tabular}{|c|c|c|c|c|c|c|c|c|c|}
\hline$\frac{\text { Panel A: SG }}{\text { (Pooled OLS) }}$ & Coefficient & $t$-Statistic & Prob. & Adjusted $R^{2}$ & $\begin{array}{c}\text { Panel B: ROA } \\
\text { (Pooled OLS) }\end{array}$ & Coefficient & $t$-Statistic & Prob. & Adjusted $R^{2}$ \\
\hline Constant & -1.67 & -1.60 & 0.11 & 0.00 & Constant & -0.19 & -3.68 & $0.00^{* * *}$ & 0.16 \\
\hline RCCG & -2.26 & -1.41 & 0.16 & & RCCG & 0.04 & 0.50 & 0.62 & \\
\hline$R C C G^{2}$ & 2.72 & 0.96 & 0.34 & & $R C C G^{2}$ & -0.03 & -0.24 & 0.81 & \\
\hline$L E V$ & 0.04 & 0.90 & 0.37 & & $L E V$ & -0.19 & -67.63 & $0.00^{* * *}$ & \\
\hline SIZE & 0.12 & 2.41 & $0.02^{* *}$ & & SIZE & 0.01 & 6.02 & $0.00^{* * *}$ & \\
\hline \multirow[t]{2}{*}{$S O P$} & -0.55 & -4.29 & $0.00^{* * *}$ & & $S G$ & 0.00 & 1.42 & 0.15 & \\
\hline & & & & & $S O P$ & -0.01 & -0.85 & 0.39 & \\
\hline $\begin{array}{l}\text { Panel C: ROE } \\
\text { (Pooled OLS) }\end{array}$ & Coefficient & $t$-Statistic & Prob. & Adjusted $R^{2}$ & $\begin{array}{l}\text { Panel D: TQ } \\
\text { (Fixed effects) }\end{array}$ & Coefficient & $t$-Statistic & Prob. & Adjusted $R^{2}$ \\
\hline Constant & -0.56 & -2.75 & $0.01^{* * *}$ & 0.00 & Constant & 44.75 & 68.56 & $0.00^{* * *}$ & 0.47 \\
\hline$R C C G$ & 0.29 & 0.94 & 0.35 & & $R C C G$ & 1.59 & 3.34 & $0.00^{* * *}$ & \\
\hline$R C C G^{2}$ & -0.26 & -0.48 & 0.63 & & $R C C G^{2}$ & -1.88 & -2.43 & $0.02^{* *}$ & \\
\hline$L E V$ & -0.02 & -2.06 & $0.04^{* *}$ & & $L E V$ & -0.02 & -0.61 & 0.54 & \\
\hline SIZE & 0.03 & 2.89 & $0.00^{* * *}$ & & SIZE & -1.95 & -64.94 & $0.00^{* * *}$ & \\
\hline$S G$ & 0.00 & 0.55 & 0.58 & & $S G$ & 0.00 & 2.22 & $0.03^{* *}$ & \\
\hline$S O P$ & 0.00 & -0.11 & 0.91 & & $S O P$ & -0.44 & -5.23 & $0.00^{* * *}$ & \\
\hline
\end{tabular}

Notes: * Significant at the $10 \%$ level. ${ }^{* *}$ Significant at the $5 \%$ level. ${ }^{* * *}$ Significant at the $1 \%$ level.

Table 6. Panel regression test results of $R C C G$ and $R C C G^{2}$ on all listed SOFs' performance.

\begin{tabular}{|c|c|c|c|c|c|c|c|c|c|}
\hline \multirow{2}{*}{$\begin{array}{c}\text { Panel A: SG } \\
\text { (Pooled OLS) }\end{array}$} & \multirow{2}{*}{ Coefficient } & \multirow{2}{*}{$t$-Statistic } & \multirow{2}{*}{ Prob. } & \multirow{2}{*}{ Adjusted $R^{2}$} & Panel B: ROA & \multirow{2}{*}{ Coefficient } & \multirow{2}{*}{$t$-Statistic } & \multirow{2}{*}{ Prob. } & \multirow{2}{*}{ Adjusted $R^{2}$} \\
\hline & & & & & (Fixed effects) & & & & \\
\hline Constant & -0.65 & -0.71 & 0.48 & 0.00 & Constant & -1.02 & -6.15 & $0.00^{* * *}$ & 0.40 \\
\hline RCCG & -1.55 & -0.85 & 0.40 & & RCCG & -0.19 & -1.44 & 0.15 & \\
\hline$R C C G^{2}$ & 2.79 & 0.78 & 0.44 & & $R C C G^{2}$ & 0.23 & 0.96 & 0.34 & \\
\hline$L E V$ & 0.24 & 1.36 & 0.18 & & LEV & -1.37 & -79.19 & $0.00^{* * *}$ & \\
\hline \multirow[t]{2}{*}{ SIZE } & 0.04 & 0.98 & 0.33 & & $S I Z E$ & 0.08 & 10.72 & $0.00^{* * *}$ & \\
\hline & & & & & $S G$ & 0.00 & 0.15 & 0.88 & \\
\hline $\begin{array}{l}\text { Panel C: ROE } \\
\text { (Pooled OLS) }\end{array}$ & Coefficient & $t$-Statistic & Prob. & Adjusted $R^{2}$ & $\begin{array}{l}\text { Panel D: TQ } \\
\text { (Fixed effects) }\end{array}$ & Coefficient & $t$-Statistic & Prob. & Adjusted $R^{2}$ \\
\hline Constant & -0.36 & -1.69 & $0.09^{*}$ & 0.00 & Constant & 30.11 & 48.23 & $0.00^{* * *}$ & 0.54 \\
\hline$R C C G$ & 0.18 & 0.42 & 0.67 & & RCCG & 0.89 & 1.87 & $0.06^{*}$ & \\
\hline$R C C G^{2}$ & -0.14 & -0.16 & 0.87 & & $R C C G^{2}$ & -1.26 & -1.47 & 0.14 & \\
\hline LEV & -0.05 & -1.21 & 0.23 & & $L E V$ & -0.16 & -2.14 & $0.03^{* *}$ & \\
\hline SIZE & 0.02 & 1.98 & $0.05^{* *}$ & & SIZE & -1.29 & -45.43 & $0.00^{* * *}$ & \\
\hline$S G$ & 0.00 & 0.18 & 0.86 & & $S G$ & 0.00 & 0.88 & 0.38 & \\
\hline
\end{tabular}

Notes: * Significant at the $10 \%$ level. ${ }^{* *}$ Significant at the $5 \%$ level. ${ }^{* * *}$ Significant at the $1 \%$ level.

Table 7. Panel regression test results of RCCG and $R C C G^{2}$ on all listed NSOFs' performance

\begin{tabular}{|c|c|c|c|c|c|c|c|c|c|}
\hline \multirow{2}{*}{$\begin{array}{c}\text { Panel A: SG } \\
\text { (Pooled OLS) }\end{array}$} & \multirow{2}{*}{ Coefficient } & \multirow{2}{*}{$t$-Statistic } & \multirow{2}{*}{ Prob. } & \multirow{2}{*}{ Adjusted $R^{2}$} & Panel B: $R O A$ & \multirow{2}{*}{ Coefficient } & \multirow{2}{*}{$t$-Statistic } & \multirow{2}{*}{ Prob. } & \multirow{2}{*}{ Adjusted $R^{2}$} \\
\hline & & & & & (Pooled OLS) & & & & \\
\hline Constant & -4.05 & -1.91 & $0.06^{*}$ & 0.00 & Constant & 0.04 & 0.41 & 0.68 & 0.21 \\
\hline RCCG & -3.03 & -1.20 & 0.23 & & RCCG & 0.04 & 0.34 & 0.73 & \\
\hline$R C C G^{2}$ & 3.46 & 0.81 & 0.42 & & $R C C G^{2}$ & -0.02 & -0.11 & 0.92 & \\
\hline$L E V$ & 0.00 & 0.21 & 0.84 & & $L E V$ & -0.17 & -55.96 & $0.00^{* * *}$ & \\
\hline \multirow[t]{2}{*}{ SIZE } & 0.23 & 2.33 & $0.02^{* *}$ & & SIZE & 0.00 & 0.83 & 0.41 & \\
\hline & & & & & $S G$ & 0.00 & 1.27 & 0.20 & \\
\hline $\begin{array}{l}\text { Panel C: ROE } \\
\text { (Pooled OLS) }\end{array}$ & Coefficient & $t$-Statistic & Prob. & Adjusted $R^{2}$ & $\begin{array}{l}\text { Panel D: TQ } \\
\text { (Fixed effects) }\end{array}$ & Coefficient & $t$-Statistic & Prob. & Adjusted $R^{2}$ \\
\hline Constant & -0.98 & -2.52 & $0.01^{* * *}$ & 0.00 & Constant & 77.54 & 34.12 & $0.00^{* * *}$ & 0.73 \\
\hline RCCG & 0.35 & 0.76 & 0.45 & & RCCG & 3.33 & 2.23 & $0.03^{* *}$ & \\
\hline$R C C G^{2}$ & -0.32 & -0.41 & 0.68 & & $R C C G^{2}$ & -3.82 & -1.65 & $0.10^{*}$ & \\
\hline LEV & 0.00 & 0.89 & 0.38 & & LEV & 2.36 & 364.34 & $0.00^{* * *}$ & \\
\hline SIZE & 0.05 & 2.56 & $0.01^{* * *}$ & & SIZE & -3.54 & -33.39 & $0.00^{* * *}$ & \\
\hline$S G$ & 0.00 & 0.45 & 0.66 & & $S G$ & 0.00 & 0.77 & 0.44 & \\
\hline
\end{tabular}

Notes: * Significant at the $10 \%$ level. ${ }^{* *}$ Significant at the $5 \%$ level. ${ }^{* * *}$ Significant at the $1 \%$ level. 
The findings of panel D presented in Tables 5 and 7 partly support Hypothesis III that there is an optimal level of effect of RCCG on long-term CP measured by $T Q$. To be more specific, the corresponding coefficients of $R C C G$ and $R C C G^{2}$ on long-term performance measures of $T Q$ for all listed firms were 1.59 and -1.88 , which are statistically significant at the $1 \%(5 \%)$ level with an explanatory power of $47 \%$ according to the adjusted $R^{2}$ (Panel D in Table 5). Table 5 also provides evidence that $L E V$ was negatively associated with the $C P$ measures of $R O A, R O E$, and $T Q$. Additionally, SIZE was positively related to the $C P$ measures of $R O A$ and $R O E$, but negatively related to $C P$ measures of TQ.SOP was negatively related to $S G$ and $T Q$ but had no significant influence on ROA and ROE.

Panel D of Table 7 demonstrates that the corresponding coefficients of RCCG and $R C C G^{2}$ on long-term performance measures of $T Q$ for NSOFs were 3.33 and -3.82 , respectively, which were statistically significant at the $5 \%(1 \%)$ level with the adjusted $R^{2}$ of 0.73 . Table 7 shows that $L E V$ was negatively related to $R O A$ and $R O E$, but was positively associated with $T Q$. The relationships between SIZE and SG and ROE were significantly positive, but the relationship between SIZE and TQ was significantly negative.

For the SOFs, Table 6 shows that neither RCCG nor $R C C G^{2}$ had a significant influence on $T Q$. $R C C G$ had no impact on $C P$, regardless of being short-term or long-term. These finding partly support hypothesis II that the effect of CCG on CP is different between SOFs and NSOFs. The results of panel regression presented in Table 6 shows $L E V$ negatively influenced the ROA and TQ of SOFs, and SIZE positively affected $R O A$ and $R O E$, while being negatively related to $T Q$.

In order to find the optimal point of RCCG to maximize the $T Q$ value, the optimal point of $R C C G$ on $T Q$ for all listed firms, Equation (8), or just NSOFs, Equation (9), can be calculated using the following estimations:

$$
T Q=44.75+1.59 R C C G-1.88 R C C G^{2}-0.02 L E V-1.95 S I Z E+0.00 S G-0.44 S O P
$$

and

$$
T Q=77.54+3.33 R C C G-3.82 R C C G^{2}+2.36 L E V-3.54 S I Z E+0.00 S G .
$$

To compute the corresponding optimal RCCG level maximizing $T Q$ for all listed firms (6) and NSOFs (7), the study takes the derivative of equations (8) and (9) with respect to RCCG and the equations then become:

$$
0=1.59-2 \times 1.88 \times R C C G
$$

and

$$
0=3.33-2 \times 3.82 \times R C C G
$$

\section{Discussion and Implications}

\subsection{Discussion}

Current studies about CCG in China generally focus on the motivation for CCG [11,16,17], though a few studies have attempted to evaluate whether CCG may influence CP in China $[10,22,34]$. This study provides a comprehensive understanding of the relationship between CCG and CP in China. Before the panel regression, we found that Chinese firms donate too little. The average RCCG was $0.03 \%$, with RCCG for NSOFs $(0.04 \%)$, being two times that of RCCG for SOFs $(0.02 \%)$. In comparison, British firms donated around $0.2 \%$ of their pre-tax profits in the 1980s [60] and American firms donated around $1.3 \%$ of their pre-tax profits in 1999 [37]. Compared to corporate donation in those countries, Chinese firms donated less than $0.1 \%$ annually between 2003 and 2016, even in years when natural disasters struck (Figure 2). Perhaps, if a clear incentive for CCG is established by showing that it can influence a corporation's $\mathrm{CP}$, then Chinese business will be more likely to donate. The empirical testing conducted in this study reveals several results that enrich the existing literature about the relationship between CCG and CP. 
First, CCG in China does not enhance firms' short-term CP measures of $S G, R O A$, and ROE, which may be one reason why a portion of CCG is declining in China which differs from Wang and Qian's [10] conclusion that CCG can increase the customer satisfaction, thus benefiting ROA. Considering Wang and Qian [11] used data from publicly listed firms between 2001 to 2006, just two years before and after the Chinese government started requiring publicly listed firms to report their CSR in 2003, they may have underestimated the influence of policy in affecting CCG on ROA. In comparison, we adopted longitudinal data from 2003 to 2016, which offer more complete information about the relationship between CCG and CP. Brammer and Millington [54] pointed out that CCG may enhance $\mathrm{CP}$ by improving a firm's reputation and demonstrated that reputation is accumulated through stakeholder judgment, and Godfrey [1] noted that CCG may nurture worker morale which enhances work efficiency and, in turn, improves $\mathrm{CP}$, which benefits $\mathrm{CP}$ in the long-term. With this in mind, CCG in China may be more of a reputation generator or efficiency accelerator rather than a form of strategic advertising.

Second, the test results provide evidence that the impact of CCG on CP is different between SOFs and NSOFs, which we expected. In other words, CCG can significantly enhance a corporation's future growth, which is measured by $T Q$, for NSOFs, though the opposite is true for SOFs. RCCG does not appear to influence $T Q$ for SOFs, though it produces some improvement in $T Q$ for NSOFs. This means that charitable giving can benefit the long-term $\mathrm{CP}$ of NSOFs but does not seem to impact SOFs. Su and $\mathrm{He}$ [23] established that NSOFs in China experience more difficulties during operation and that those firms must engage in CCG in order to protect property rights and preserve political connections that generate good performance. Gao et al. [20] claimed that CCG in China may decrease environmental uncertainty. Our study provides empirical evidence to support that CCG is a traditional philanthropy approach that helps NSOFs benefit in the long-term rather than strategic philanthropy that enhances $\mathrm{CP}$ in the short-term.

Third, there is an optimal point for the positive effect of CCG on long-term CP. The inverted U-shaped relationship between $R C C G$ and $T Q$ means that $T Q$ only continues to grow with $R C C G$ until it surpasses the optimal point. Then, $R C C G$ is negatively related to $T Q$. By separating all listed firms into SOFs and NSOFs, our findings suggest that the relationship between RCCG and TQ for NSOFs is an inverted U-shaped with an explanation power as high as $73 \%$, but there is no significant relationship between $R C C G$ and $T Q$ for SOFs.

According to Equation (6), for all Chinese listed firms, the optimal point at which RCCG maximizes $T Q$ is $0.423 \%$. Figure 3 shows the inverted $U$-shaped relationship between RCCG and TQ. Likewise, Equation (7) shows that the optimal point at which RCCG maximizes TQ for NSOFs is $0.437 \%$ (Figure 4 ).

\subsection{Policy Implications}

Considering the optimal point of RCCG that maximizes $T Q$ is about 14 times higher $(0.423$ divided by 0.03$)$ than the sample mean of RCCG $(0.03 \%)$ for all Chinese firms from 2003 to 2016, and the point of RCCG that maximizes TQ for NSOFs is about 11 times ( 0.437 divided by 0.04$)$, these conclusions can provide meaningful policy implications.

First, firms may donate more to increase public preference. Compared to donations by American and British firms, Chinese firms donate much less, at just $0.03 \%$ of the sales $(0.04 \%$ for NSOFs, and $0.02 \%$ for SOFs). Since the future growth measures of $T Q$ continue to grow before RCCG for all listed firms (NSOFs) reaches $0.423 \%(0.437)$, firms in China may want to consider donating more in order to maximize the positive influence of CCG.

Second, because they have access to more resources than NSOFs, SOFs should donate more to support the good of society. Although our empirical results show that CCG does not enhance CP for SOFs, the static table shows that donations by SOFs are half that of NSOFs on average. Given SOFs have natural political connections [49], SOFs are in a position to benefit the community more rather than just building or maintaining political connections. 


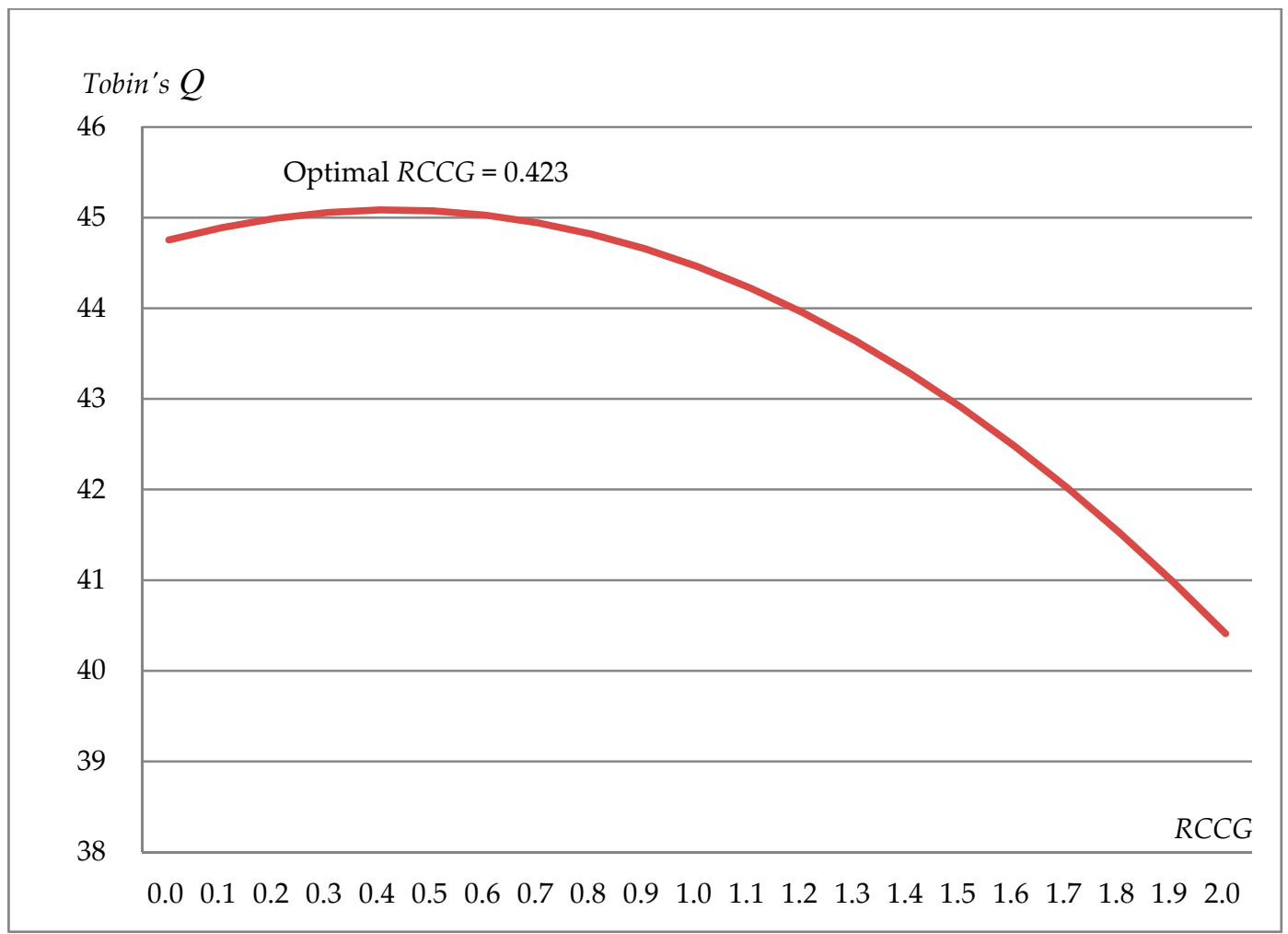

Figure 3. The inverted U-shaped relationship between RCCG and Tobin's Q (TQ): All listed SOFs and NSOFs.

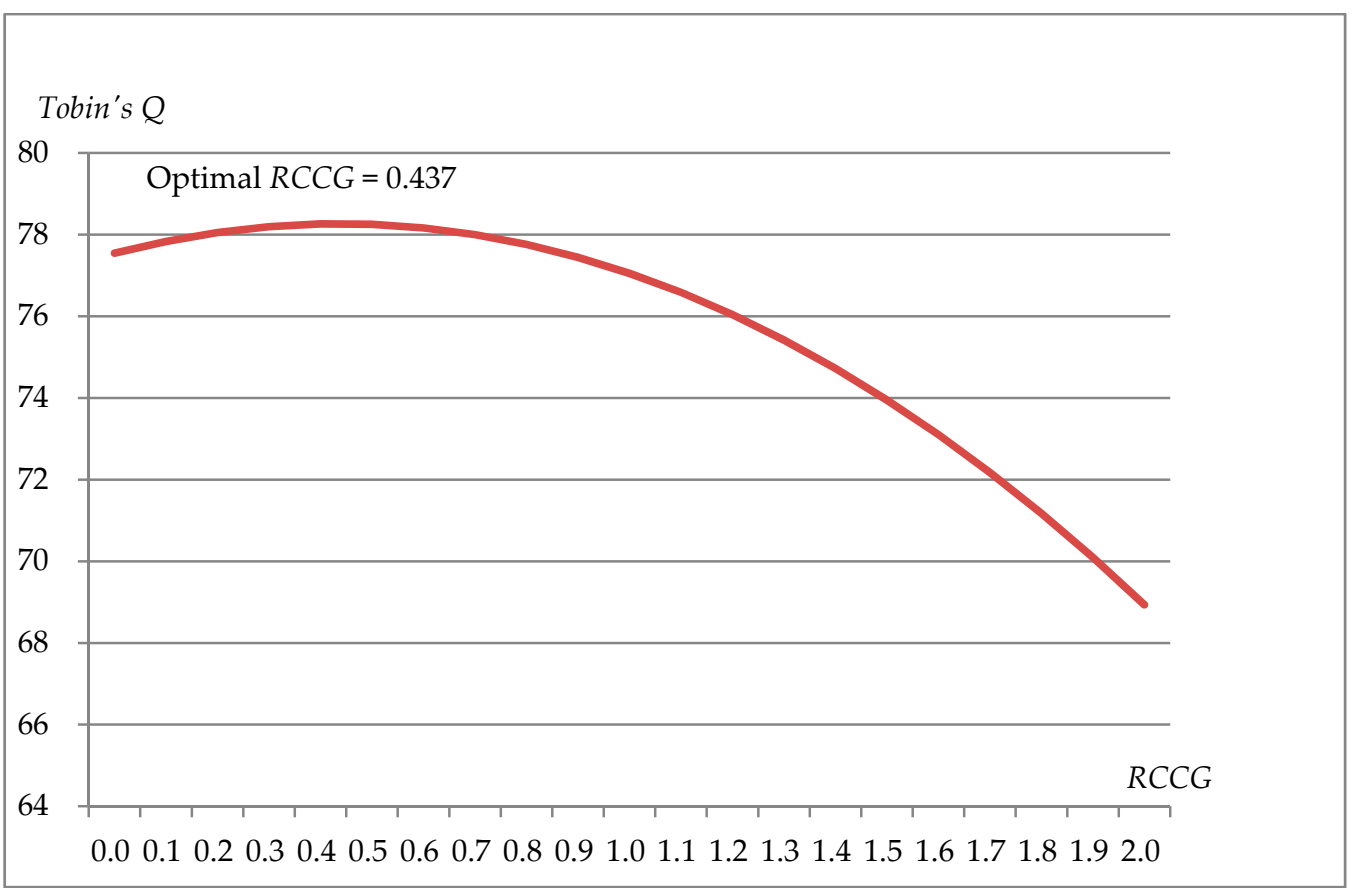

Figure 4. The inverted U-shaped relationship between RCCG and TQ: NSOFs.

Third, corporate managers in China would do well to assess the value of CCG in the long-term rather than in just the short-term. Carroll [30] stated that strategic philanthropy should fit the firm's mission, goals, and objectives, and Godfrey [1] pointed out that CCG is a transfer of wealth. So, managers should be prepared to show how CCG can help their bottom line; otherwise, CCG may be seen as an action that managers use solely to benefit their own interests $[2,61,62]$. 


\section{Limitations and Future Study Considerations}

The main limitations of this study are as follows. First, we were limited by the data and only tested the relationship between the CCG and CP of publicly listed firms in China. Considering the micro-operation environments of publicly listed firms and non-listed firms are different, meaningful future studies should focus on how CCG influences non-listed firm performance. Second, this study shows that CCG may influence long-term performance, but does not identify how CCG benefits long-term performance. Given that long-term performance may be enhanced through higher work efficiency, good firm image, and easier access to resources and/or support, studies will need to stay current by focusing on political motivations for participating in CCG as well as how CCG influences firm image and work efficiency in China.

Author Contributions: Conceptualization, K.W. and M.-H.C.; methodology, M.-H.C.; formal analysis, Y.M., Z.W. and T.W.; data collection, Z.W. and T.W.; writing-original draft preparation, Y.M.; writing-review and editing, C.-H.S.; visualization, C.-H.S.; supervision, K.W. and M.-H.C.

Funding: This research received no external funding.

Conflicts of Interest: The authors declare no conflict of interest.

\section{References}

1. Godfrey, P.C. The relationship between corporate philanthropy and shareholder wealth: A risk management perspective. Acad. Manag. Rev. 2005, 30, 777-798. [CrossRef]

2. Brown, W.; Helland, E.; Smith, K. Corporate philanthropic practices. J. Corp. Financ. 2006, 12, 855-877. [CrossRef]

3. Navarro, P. Why do corporations give to charity? J. Bus. 1988, 61, 65-93. [CrossRef]

4. Wang, H.; Choi, J.; Li, J. Too little or too much? Untangling the relationship between corporate philanthropy and firm financial performance. Organ Sci. 2008, 19, 143-159. [CrossRef]

5. Barnett, M.L. Stakeholder influence capacity and the variability of financial returns to corporate social responsibility. Acad. Manag. Rev. 2007, 32, 794-816. [CrossRef]

6. Berman, S.L.; Wicks, A.C.; Kotha, S.K.; Jones, T.M. Does stakeholder orientation matter? The relationship between stakeholder management models and firm financial performance. Acad. Manag. J. 1999, 42, 488-506.

7. Griffin, J.J.; Mahon, J.F. The corporate social performance and corporate financial performance debate twenty-five years of incomparable research. Bus. Soc. 1997, 36, 5-31. [CrossRef]

8. Seifert, B.; Morris, S.A.; Bartkus, B.R. Having, giving, and getting: Slack resources, corporate philanthropy, and firm financial performance. Bus. Soc. 2004, 43, 135-161. [CrossRef]

9. Gao, F.; Faff, R.; Navissi, F. Corporate philanthropy: Insights from the 2008 Wenchuan earthquake in China. Pac.-Basin Financ. J. 2012, 20, 363-377. [CrossRef]

10. Lin, S.; Wang, J.; Yao, S.; Chen, J. Market reactions and corporate philanthropy: A case study of the Wenchuan earthquake in China. J. Contemp. China 2012, 21, 299-315.

11. Wang, H.; Qian, C. Corporate philanthropy and CFP: The roles of stakeholder response and political access. Acad. Manag. J. 2011, 54, 1159-1181. [CrossRef]

12. Sina News. Available online: http:/ / gongyi.sina.com.cn/gyzx/2011-05-10/095826233.html (accessed on 10 May 2011).

13. Zhang, R.; Rezaee, Z.; Zhu, J. Corporate philanthropic disaster response and ownership type: Evidence from Chinese firms' response to the Sichuan earthquake. J. Bus. Ethics 2009, 91, 51-63. [CrossRef]

14. Yang, T. Annual Report on China's Philanthropy Development; Social Sciences Academic Press: Beijing, China, 2017; p. 17. ISBN 978-7-5201-0923-9.

15. Gao, Y. Philanthropic disaster relief giving as a response to institutional pressure: Evidence from China. J. Bus. Res. 2011, 64, 1377-1382. [CrossRef]

16. Li, S.; Song, X.; Wu, H. Political connection, ownership structure, and corporate philanthropy in China: A strategic-political perspective. J. Bus. Ethics 2015, 129, 399-411. [CrossRef]

17. Lin, K.J.; Tan, J.; Zhao, L.; Karim, K. In the name of charity: Political connections and strategic corporate social responsibility in a transition economy. J. Corp. Financ. 2015, 32, 327-346. [CrossRef] 
18. Ma, D.L.; Parish, W.L. Tocquevillian moments: Charitable contributions by Chinese private entrepreneurs. Soc. Forces 2006, 85, 943-964. [CrossRef]

19. Long, C.; Yang, J. What explains Chinese private entrepreneurs' charitable behaviors?-A story of dynamic reciprocal relationship between firms and the government. China Econ. Rev. 2016, 40, 1-16. [CrossRef]

20. Gao, Y.; Lin, L.Y.; Yang, H. What's the value in it? Corporate giving under uncertainty. Asia Pac. J. Manag. 2017, 34, 215-240. [CrossRef]

21. Wang, Z. Corporate Governance, Policies and Public Listing: The case of Chinese State-owned Enterprises. In Corporate Governance and CSR: A Focus on Emerging Markets; Boubaker, S., Nguyen, D.K., Eds.; World Scientific Publishing: Singapore, 2014; p. 63. ISBN 978-9-8145-2037-9.

22. Zhang, M.; Xie, L.; Xu, H. Corporate philanthropy and stock price crash risk: Evidence from China. J. Bus. Ethics 2016, 139, 595-617. [CrossRef]

23. Su, J.; He, J. Does giving lead to getting? Evidence from Chinese private enterprises. J. Bus. Ethics 2010, 93, 73-90. [CrossRef]

24. Chen, M.H.; Lin, C.P. The impact of corporate charitable giving on hospitality firm performance: Doing well by doing good? Int. J. Hosp. Manag. 2015, 47, 25-34. [CrossRef]

25. Yu, Y.; Choi, Y. Corporate social responsibility and firm performance through the mediating effect of organizational trust in Chinese firms. Chin. Manag. Stud. 2014, 8, 577-592. [CrossRef]

26. Agle, B.R.; Mitchell, R.K.; Sonnenfeld, J.A. Who matters to CEOs? An investigation of stakeholder attributes and salience, corporate performance, and CEO values. Acad. Manag. J. 1999, 42, 507-525.

27. Heinze, D.; Sibary, S.; Sikula, A. Relations among corporate social responsibility, financial soundness, and investment value in 22 manufacturing industry groups. Ethics Behav. 1999, 9, 331-347. [CrossRef]

28. Jin, K.R.; Drozdenko, R.G. Relationships among perceived organizational core values, corporate social responsibility, ethics, and organizational performance outcomes: An empirical study of information technology professionals. J. Bus. Ethics 2010, 92, 341-359. [CrossRef]

29. Margolis, J.D.; Walsh, J. People and Profits? The Search for a Link between a Company's Social and Financial Performance; Lawrence Erlbaum Associates: Mahwah, NJ, USA, 2001.

30. Carroll, A.B. Corporate social performance measurement: A commentary on methods for evaluating an elusive construct. Res. Corp. Soc. Perform. Policy 1991, 12, 385-401.

31. Friedman, M. The social responsibility of business is to increase its profits. New York Times Magazine, 13 September 1970; 122-126.

32. Porter, M.E.; Kramer, M.R. The competitive advantage of corporate philanthropy. Harv. Bus. Rev. 2002, 80, 5-16.

33. Liang, H.; Renneboog, L. Corporate donations and shareholder value. Oxf. Rev. Econ. Policy 2017, 33, 278-316. [CrossRef]

34. Williamson, O. The Economics of Discretionary Behavior: Managerial Objectives in a Theory of the Firm; (Ford Foundation Doctoral Dissertation Series; Prentice Hall: Upper Saddle River, NJ, USA, 1964.

35. Campbell, L.; Gulas, C.S.; Gruca, T.S. Corporate giving behaviour and decision-maker social consciousness. J. Bus. Ethics 1999, 19, 375-383. [CrossRef]

36. Lev, B.; Petrovits, C.; Radhakrishnan, S. Is doing good good for you? How corporate charitable contributions enhance revenue growth. Strat. Mgmt. J. 2010, 31, 182-200. [CrossRef]

37. Seifert, B.; Morris, S.A.; Bartkus, B.R. Comparing big givers and small givers: Financial correlates of corporate philanthropy. J. Bus. Ethics 2003, 45, 195-211. [CrossRef]

38. Thompson, A.A.; Strickland, A.J. Strategic Management: Concepts and Cases, 13th ed.; Mcgraw-Hill: New York, NY, USA, 2003.

39. Saiia, D.H.; Carroll, A.B.; Buchholtz, A.K. Philanthropy as strategy when corporate charity "begins at home". Bus. Soc. 2003, 42, 169-201. [CrossRef]

40. Post, J.E.; Waddock, S.A. Strategic philanthropy and partnerships for economic progress, philanthropy and economic development. In Philanthropy and Economic Development; America, R.F., Ed.; Greenwood Press: Westport, CT, USA, 1995; pp. 167-191.

41. Lewin, D.; Sabater, J.M. Corporate Philanthropy and Business Performance. In Corporate Philanthropy at the Crossroads; Burlingame, D.F., Young, D.R., Eds.; Indiana University Press: Bloomington, IN, USA, 1996; pp. 105-112.

42. Weeden, C. Corporate Social Investing; Berrett-Koehler Press: San Francisco, CA, USA, 1998. 
43. Wang, K.; Chen, M.H.; Lin, C.P.; Gillard, E. The impact of tourism firm's philanthropy decision on its business objective. Tour. Econ. 2018, 24, 503-509. [CrossRef]

44. Hategan, C.-D.; Curea-Pitorac, R.-I. Testing the correlations between corporate giving, performance and company value. Sustainability 2017, 9, 1210. [CrossRef]

45. Gautier, A.; Pache, A. Research on corporate philanthropy: A review and assess. J. Bus. Ethics 2015, 126, 343-369. [CrossRef]

46. Chen, M.H.; Lin, C.P.; Tian, L.; Yang, Y. A theoretical link between corporate giving and hospitality firm performance. Int. J. Hosp. Manag. 2017, 66, 130-134. [CrossRef]

47. Chen, M.H. The economy, tourism growth and corporate performance in the Taiwanese hotel industry. Tour. Manag. 2010, 31, 665-675. [CrossRef]

48. Lu, C.; Zhao, X.; Dai, J. Corporate social responsibility and insider trading: Evidence from China. Sustainability 2018, 10, 3163. [CrossRef]

49. Ye, K.; Zhang, R. Do lenders value corporate social responsibility? Evidence from China. J. Bus. Ethics 2011, 104, 197-206. [CrossRef]

50. Zhang, M.; Ma, L.; Su, J.; Zhang, W. Do suppliers applaud corporate social performance? J. Bus. Ethics 2014, 121, 543-557. [CrossRef]

51. Chen, Z.; Cao, Y. Chinese private corporate philanthropy: Social responsibility, legitimacy strategy, and the role of political capital. Chin. Sociol. Rev. 2016, 48, 108-136. [CrossRef]

52. China Stock Market \& Accounting Research Database. Available online: http://us.gtadata.com/Login/ Index?versionswitch=\&control= (accessed on 27 January 2017).

53. China Information. Available online: http://www.cninfo.com.cn/ (accessed on 1 August 2017).

54. Brammer, S.; Millington, A. Does it pay to be different? An analysis of the relationship between corporate social and financial performance. Strat. Mgmt. J. 2008, 29, 1325-1343. [CrossRef]

55. Chung, K.H.; Pruitt, S.W. A simple approximation of Tobin's q. Financ. Manag. 1994, 23, 70-74. [CrossRef]

56. Baltagi, B.H. Econometric Analysis of Panel Data, 3rd ed.; John Wiley \& Sons, Ltd.: West Sussex, UK, 2005.

57. Hsiao, C. Analysis of Panel Data; Cambridge University Press: Cambridge, UK, 1986.

58. Hausman, A. Specification tests in econometrics. Econometrica 1978, 46, 1251-1271. [CrossRef]

59. Dimitrios, A. Applied Econometrics: A Modern Approach Using EViews and Microfit; Palgrave Macmillan: Basingstoke, UK, 2005.

60. Campbell, D.; Moore, G.; Metzger, M. Corporate philanthropy in the UK 1985-2000: Some empirical findings. J. Bus. Ethics 2002, 39, 29-41. [CrossRef]

61. Chen, J.; Wang, D.; Tong, J.; Zhang, F. Corporate philanthropy and tunneling: Evidence from China. J. Bus. Ethics 2018, 150, 135-157. [CrossRef]

62. Balotti, R.F.; Hanks, J.J., Jr. Giving at the office: A reappraisal of charitable contributions by corporations. Bus. Lawyer 1999, 54, 956-996. 